\title{
Diplomatic Representations of Mass Violence
}

"If you want to make peace in Darfur through negotiations, you have to deal with the Sudanese government and you have to deal with the people who hold the power in the Sudanese government, and that includes Omar al-Bashir. If you want to achieve justice through the International Criminal Court, well, then you should stigmatize someone who is indicted. You shouldn't talk to Omar al-Bashir. Right?”

One of my interviewees from the world of foreign policy and diplomacy thus succinctly addressed a key difference between the justice field and that of foreign policy, where diplomacy is a central tool. Actors in the latter seek to include players in the field, no matter their responsibility for immense suffering; actors in the former seek to exclude certain players. Foreign policy is not identical with diplomacy, of course. Threats of military intervention and the potential of economic sanctions, positive and negative, are among its tools. And so are hints at judicial consequences for human rights offenses. Diplomats may use such threats (and rewards) as they engage with leaders and agents of foreign governments. But engage with them they do, and they thus depend on maintaining network ties-diplomatic capital. Diplomacy differs from the justice field in another essential way: it is oriented toward substantive outcomes, in stark contrast to the procedural orientation of criminal proceedings. What are the consequences of these differences for representations of the Darfur conflict in the diplomatic field? 
Previous scholarship has identified the cautious rhetoric of governments regarding the term genocide. Samantha Power (2002), now the US ambassador to the United Nations, argued in her Pulitzer Prizewinning book, A Problem from Hell: America and the Age of Genocide, in the case of the United States: "The U.S. Government not only abstains from sending its troops, but it takes very few steps along a continuum of intervention to deter genocide. U.S. officials . . render the bloodshed two-sided and inevitable, not genocidal. ... They avoid use of the term 'genocide"' (xviii). Political scientist Karen Smith (20I0) identifies similar patterns for France, Germany, and the United Kingdom, for post-World War II history generally and for these countries' specific responses to mass violence in Bosnia, Rwanda, Kosovo, and Darfur: "[Q]uite a few European governments were hostile to the Genocide Convention, and some took decades to ratify it. Furthermore, European governments are not keen on using the term to describe atrocities" (2).

Power (2002) and K. Smith (2010) do not just describe but also seek to explain the cautious rhetoric of governments. Their argument is based on the assumption that rational foreign policy actors seek to avoid pressure toward intervention, possibly by military means, given that such intervention is almost always unpopular among their countries' populations. ${ }^{\mathrm{I}}$ This explanation is meaningful but seems incomplete. My data suggest that it needs to be complemented by a theory that takes seriously conditions in the diplomatic field and the habitus it generates. The government of the perpetrating country is a player in that field, and diplomats depend on active cooperation by its agents to pursue their negotiations toward substantive outcomes. It is this field condition that prompts their caution about using exclusionary rhetoric, a hallmark of the institutional logic of criminal law, as well as their caution against the use of direct language, even when rational thought about the political consequences of interventions has not been activated. In short, governments are reluctant to use strong means, especially military intervention, in cases of genocide or mass atrocities in distant lands. This reluctance is reinforced by the inclination of actors in the diplomatic field to capitalize on past social ties in international relations, a disposition that has become part of the habitus of diplomats. Avoiding strong language and strategies that would force a breakdown of communication appears natural to them.

Just as field theory helps explain differences and competition between narratives about mass violence generated in the criminal justice versus humanitarian aid fields, it suggests that we should expect yet another distinctive representation in the field of diplomacy with its unique constellation 
of actors. My interviews with diplomats and the documents I gathered from foreign ministries show, not surprisingly, that many participants in the foreign policy and diplomacy fields, just like their counterparts in the humanitarian aid field, are cautious to hostile in their views regarding the notion of individual criminal liability for grave human rights violations. They resent the heart of the justice cascade. In fact, their accounts often challenge the idea that responsibility can be attributed to specific individuals or that doing so, even where possible, would be "helpful."2

While the display of a common denominator, or master narrative, in diplomatic accounts of the Darfur conflict is in line with field theory, I nevertheless expect foreign policy and its narratives to vary in cross-national comparison-a topic I address in the following chapter. In addition to a common denominator and cross-national variation in responses to Darfur, I further anticipate variation within countries. Foreign policy makers differ in terms of educational background, career paths within the foreign service, and especially the specific organizational units within departments of foreign affairs in which they formulate their positions on mass atrocities. While my interviewees paid at least lip service to the mission of the International Criminal Court, only some clearly identified with its mission. Others-even within the same country-displayed skepticism, in principle or in practice.

This chapter begins with a brief overview of relevant data. I then show how the field of diplomacy presents itself in the case of Darfur. What goals do diplomats identify with? Which actors matter in this pursuit? What sources of information do diplomats draw from? How does their habitus correspond with the field, and what traces from diachronically (education) and synchronically (nation, organizational unit) overlapping fields do we find? Next, I sketch, based on my interviews, a diplomatic narrative of the Darfur conflict. As in previous chapters, I consider causes of the conflict, central actors who bear responsibility for the violence, victimization, and suffering, as well as the frame deemed appropriate for an interpretation of the violence. I indeed identify a diplomatic master narrative, approximating an ideal type, a narrative that starkly contrasts with criminal justice representations of the same event.

INTERVIEWS, FOREIGN MINISTRY WEBSITES, AND THE MEDIA DATA SET

I conducted a total of twelve semistructured interviews with thirteen Darfur experts in foreign ministries, each lasting between one and two 
hours and yielding some five hundred pages of transcript. Interviewees included actors from all six European countries considered throughout this study-Austria, France, Germany, Ireland, the United Kingdom, and Switzerland, as well as a seventh, the Netherlands. A small conference on representations of the Darfur conflict held at the Rockefeller Bellagio Center included US diplomats from the Bill Clinton and George W. Bush administrations and provided opportunities for formal and informal communication on the issues addressed in my questionnaire. These American diplomats and two European interviewees also supplied me with publications they had authored on the Darfur conflict.

Diplomat interviewees were all engaged in work on Sudan generally, Darfur specifically, issues of international law and the ICC, or some combination of these. Eight were placed in their ministry's political divisions, where treaties are negotiated, arbitration is organized, and communication is cultivated with other governments, including hostile ones. Two worked in legal divisions, with responsibilities for international justice institutions, and one in her ministry's development and humanitarian aid division. Two respondents were at the periphery of the field, in research institutions with consulting and support functions for their respective foreign ministries.

Interviewees had various educational backgrounds. Five held law degrees (two with specializations in international law, one in combination with political science); four held degrees in political science; and one, a degree in international public policy (supplemented by economics and English literature degrees). While law and political science thus dominated, there were exceptions: one respondent had earned his $\mathrm{PhD}$ with a thesis on the history of his country's foreign policy; another held degrees in history and geography with a focus on Africa; and yet another had a background in natural science. Not surprisingly, two of the respondents with law degrees were placed in legal divisions of their foreign ministries. In line with insights from earlier chapters we should expect the lawyers in legal divisions of foreign ministries to produce a Darfur narrative that most clearly deviates from the ideal-typical representation of the diplomacy field, one that may well show an affinity with the justice narrative.

Many interviewees, even among the younger cohorts, had substantial foreign experience. Three had done part of their studies abroad, and two of these had earned advanced degrees at foreign universities (both in the United States). Eight had spent substantial portions of their foreign service careers abroad. Some had visited Sudan, including Darfur, 
and three had worked for extensive periods in their countries' missions in Khartoum. There they had regularly interacted with representatives of the Sudanese state. Within the world of diplomacy, these three actors are structurally closest to that part of the diplomatic field that encompasses the Sudanese state. Their account of the conflict should most evidently be in line with the diplomatic master narrative on Darfur and most distinct from the criminal justice narrative.

Supplementing the interview data is a content analysis of websites of the foreign ministries, specifically foreign ministry press releases found thereon for seven of our eight countries. ${ }^{3}$ I also draw on findings from the Darfur media data set to compare diplomatic sentiments across countries with patterns from the societies in which they are embedded.

THE FIELD OF DIPLOMACY AND THE HABITUS OF ITS ACTORS

\section{Interacting with the Sudanese State}

When I conducted my interviews, between December 2010 and July 20II, two major diplomatic efforts were under way. The first was the implementation of the Comprehensive Peace Agreement (CPA) of 2005 , intended to settle the devastating Second Sudanese Civil War between the country's North and South, with its estimated two million dead. The second was the most recent major attempt to bring peace to Darfur: the Doha peace negotiations, following the ill-fated Abuja Peace Agreement of 2006. These Doha negotiations were finalized in the spring of 2OII, after two and a half years of diplomatic labor. Both processes loomed large in the minds of the diplomats I interviewed, and colored their reading of the conflict.

The CPA is also known as the Naivasha Agreement, named after the Kenyan town where most of its components were negotiated between 2002 and 2004 and where the final comprehensive agreement was signed on January 9, 2005. The contracting parties were the government of Sudan and the Sudan People's Liberation Movement (SPLM). The process was advanced by the Intergovernmental Authority for Development (IGAD), a trading group of East African countries, and the IGAD Partners, a consortium of donors that included three of the countries considered in this analysis (i.e., the Netherlands, United Kingdom, and United States). The CPA resulted in the formation of the shaky Government of National Unity for Sudan after 2005 and in the 
withdrawal of northern Sudanese troops from South Sudan in January 2008. As part of the CPA, a referendum was held in January $201 \mathrm{I}$ in which the population of southern Sudan almost unanimously voted to separate from the North. We know today that the establishment of the new country, enthusiastically celebrated by the South Sudanese population at the time, but accompanied by cautious commentary from political analysts and informed journalists, resulted in a state at risk of failing and in a new, brutal civil war between military factions organized around fiefs, partly on the basis of ethnicity (with the Nuer and Dinka as the dominant groups), within the South. Since late 2013 , the death toll has climbed with frightening speed. Yet in $20 \mathrm{I}$ I the implementation of the CPA appeared as a major triumph of diplomacy. After all, a long and bloody civil war had been settled by diplomatic means. The question on the minds of many interviewees was whether the government of Sudan would cooperate until the very end and whether it would indeed allow independence to take place and would permit control over massive oil fields to shift to its new neighbor. Simultaneously, would the Sudan government continue the Doha peace process on Darfur, then approaching a conclusion? Or would Khartoum at the last moment destroy the fruit of hard diplomatic labor that was expected to replace a legacy of mass violence with enduring peace?

A diplomat from the political division of the foreign ministry of a large European country who had previously spent years in his country's embassy in Khartoum spoke about diplomatic efforts focused on Sudan. His words illustrate well a diplomatic strategy vis-à-vis the CPA process and the role attributed to the government of Sudan: "Our first priority is securing the Comprehensive Peace Agreement and to accompany it all the way through [to] its, ideally complete, implementation. That is especially, right now, that the referendum on the independence of South Sudan will be held, and then the, in all likelihood, subsequent independence of South Sudan [will take effect] in July 20II. That is the first pillar" (author's translation).

The interviewee then addressed the risk of South Sudan becoming a "pre-failed state," an outcome "the international community cannot afford." Contributing to a functioning infrastructure in South Sudan was thus considered the second component of his country's policy. The third pillar linked the CPA to the Doha negotiations on Darfur: "Of course there will be no peace in the region if the Darfur problem does not get resolved. That means we have to accompany the Doha peace process and promote it in a way that it will result, over [the] short 
or long [term], in a sustainable peace solution for Darfur, and that then also the UNAMID mission of the United Nations will become a success" (author's translation).

This interviewee, himself head of an interdepartmental task force on Darfur, reported with pride that units within his ministry had come to an agreement regarding their Sudan policy: the most important pursuit vis-à-vis Sudan for 20I0-20I I would be to help the peace negotiations in Doha succeed, with all parties to the conflict included.

The final pillar of this country's policy consequently addresses the role of the Sudan government in this process:

And the fourth pillar is the inclusion of northern Sudan into this peace solution and, of course, the stabilization of this region. Because, upon close inspection of the last five years of the implementation of the CPA and the Darfur War, there was always one evildoer, and this evildoer has then, for pure survival reasons or simply in opposition to international pressure against him, torpedoed all peace solutions-or could torpedo all peace solutions. He has done it, too, in the past. The proper key to a peace in the region is thus the inclusion of the regime in Khartoum in the peace solution and its liberation from international isolation, in combination with appropriate incentives to which the international community will then have to stick. (author's translation)

This explanation illustrates well the premium placed on diplomatic efforts and on the inclusion of the government of Sudan in the process of settling the conflict, not just between Sudan and South Sudan but also within Darfur. The same interviewee insisted that appropriate methods include bracketing the ICC charges against al-Bashir ("gar nicht darüber reden") and providing the government with incentives, though with an undertone of potential sanctions should the incentives not work ("wir können auch anders"). This interview segment illustrates that the government of Sudan plays an even more powerful role in the field of diplomacy than it does in the field of humanitarian aid. At issue in diplomacy is active cooperation and compromising at the country's leadership level; in humanitarianism, the issue is toleration (and possibly cooperation) at lower levels of state administration, and in exchange for resources provided and services delivered by NGOs and international agencies.

The statements cited above are characteristic of sentiments I encountered in the world of diplomacy generally. One interviewee from another large European country expressed similar hopes and caution regarding the government of Sudan: "There was obviously a lot of work being put 
in, internationally, into the North-South agreement. . . . After twenty years, two million people killed, there was such desire to bring that to a conclusion and get the CPA signed that people said: 'Look at Darfur, it is terrible, but we can't rock the boat, we can't jeopardize the CPA negotiations.'" Again, the argument goes, the government of Sudan must be kept in the game, treated with respect, even offered incentives, so as to capitalize on the diplomatic investments of previous years. One interviewee spoke with pride about his (relatively small) country's status as a formal witness of the CPA and its chairing of one of three working groups of the Assessment and Evaluation Commission, the international body set up to observe the implementation of the CPA.

Diplomats also report many less visible activities. One of the small European countries with substantial expertise in the banking sector, for example, advised the government of Sudan on issues of debt relief should the North have to shoulder, as a consequence of the CPA, the debt of the entire country. The same country provided the South with expertise on writing a federal constitution for a multiethnic country, a feature both provider and recipient shared. This country had hosted numerous delegations from Sudan, including ministers, legislators, and financiers from the North and South, for seminars on constitution building, currency, and finance.

Within the world of diplomacy, clear rationales seem to drive most diplomatic efforts. Yet actors in the diplomatic field also identify strongly with their role. In fact, their habitus is shaped by their position in the diplomatic field. They have internalized the field's doxa, its matter-of-course assumptions. Diplomats intuitively know what political science research confirms: that as mediators they can succeed only if they strongly relate to the issue at stake, take a moderate position, and abstain from bias toward any one side in the conflict (Kydd 2006).4 One interviewee, from a smaller European country with a special reputation for its expertise in mediation, reported on his ministry's chief negotiators:

We had two mediators in the Darfur conflict, both with substantial experience and expert knowledge in the areas of mediation, conflict analysis, constitutional law, peace and conflict research, regional analysis [on] Sudan and [the] Horn of Africa.... They were able to play a significant role in the course of the peace processes, one in Abuja; the other spent over three years in Khartoum and was especially involved in the Doha negotiations in support of chief mediator Jibril Basole. Both experts also work as coaches and university instructors. They thus connect theory and praxis in many ways. [Commenting on demanding travel schedules and the resulting hardship for 


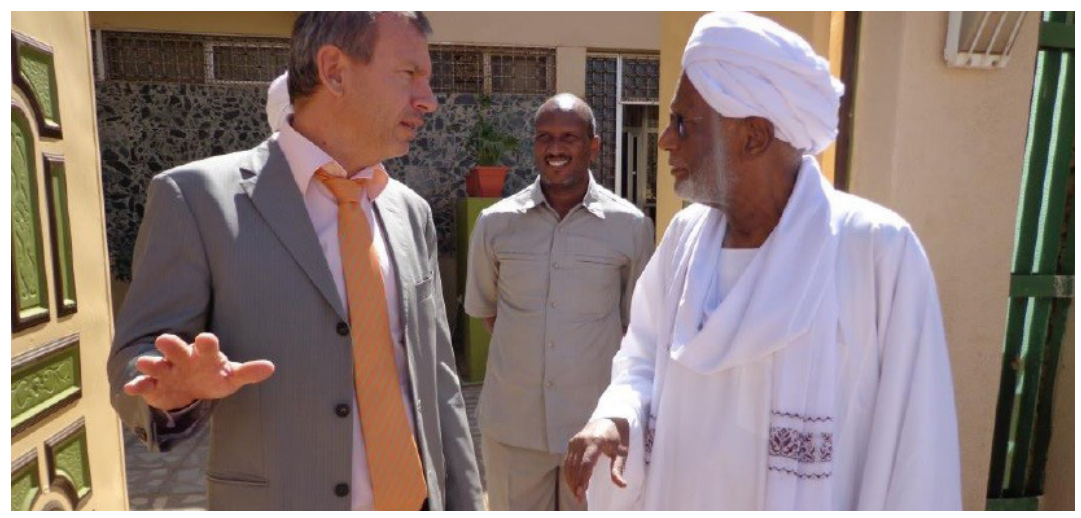

Figure I 6. Ambassador Tomas Ulicny, head of the EU delegation to Sudan, and Dr. Hassan El Turabi, head of the Popular Congress Party, engage in peace negotiations, Khartoum, February 3, 20I 5.

personal and family life:] People who devoted their hearts and souls to these processes [mit Herzblut in diesen Prozessen waren], who probably developed a sense: "I can make a difference; I can motivate these people so that they will finally agree to peace." (author's translation)

In short, diplomats engaged in negotiation and consulting activities in a field in which the government of Sudan and its agents played a key role. Their efforts, with which interviewees strongly identified, are directed at the achievement of peace. Some invested heavily in these efforts, at the price of enduring demanding travel schedules and frequent and long-term absences from home and family, reflecting a strong identification with their mission.

\section{Hierarchies of Goals-And the Status of Justice among Them}

Settling conflict and establishing peace is obviously a central foreign policy goal in the context of Darfur policies. But how does this goal relate to the others I inquired about in my interviews: the integrity of the sovereign state, the survival of affected populations, and-of special interest here-the pursuit of justice? How do diplomats rank these goals relative to each other? Where do they perceive conflicts between them? Do they see ways of resolving potential contradictions?

Segments from an interview I conducted with a diplomat from one of the large European countries, quoted above, strongly reflect diplomatic reasoning. They highlight as the primary goal replacing war and violent 
conflict with peace by means of diplomatic negotiations. The goal of justice ought to be bracketed and, if pursued at all, used as a bargaining chip. Four of the diplomats I interviewed-all from the political divisions of their ministries-clearly followed this line of reasoning. Especially telling are the words of one respondent from the sub-Sahara unit of the foreign ministry of a smaller European country, a diplomat with years of experience in his country's mission in Khartoum. Arguing for the primacy of the peace mission, he also commented on the role of justice and the ICC in relation to that primary goal:

First, we should come to some kind of peace agreement. And then you should work on reconciliation and transitional justice.... The underlying problem is not the question of cooperation with the ICC, but is the culture of impunity which prevails until now in Sudan. ... I think one should put emphasis on strengthening the national legal system in Sudan. The ICC has a very limited role or mandate, and it has not the capacity to investigate all cases of crimes that have been committed in Darfur. So you need to come to strengthening the legal system. I think the African Union panel on Darfur ... made recommendations on the issue of peace, reconciliation and justice for Darfur. Without going into a competition with the ICC, they managed to keep these on two separate tracks. And I think these recommendations were welcomed by the Sudanese government. And I personally would put more emphasis on trying to convince the Sudanese to implement all of these recommendations instead of repeating every time that they should cooperate with the ICC, because it doesn't bring anyone any further. [Colleagues in the fragile-states unit] agree, and also the colleagues at the embassy in Khartoum, since they are working on a daily basis on the peace process.... You cannot expect to have an international trial against the president who is at the same moment an important player in the peace process.

This interviewee called his own position "pragmatic." While he insisted that the ICC indictments complicated the peace process, he conceded that they "could also pressure in a positive way." Instead of opposing the goal of justice, he wanted it pursued later and by means other than the ICC. He thus tempered his general skepticism toward the ICC with a call for developing the justice system in Sudan and a plea to put an end to the "culture of impunity."

Other interviewees from political divisions also had reservations about the ICC, even if they do not reject transitional justice per se. One suggested that justice should not be pursued "right away," and that there are various alternatives to the ICC. Another expressed principled support for the ICC as an institution, acknowledging its potential for a long-term civilizing effect, but insisted that it should be placed on a back burner in the Darfur case. A somewhat different argument was 
presented by a diplomat who believed that justice is a precondition of peace, but who called-in vague terms-for a different kind of justice than what the ICC has to offer. Some interviewees articulated general skepticism about the ICC; others objected to the way then-chief prosecutor Luis Moreno-Ocampo handled the proceedings. Moreno-Ocampo of course had achieved substantial fame earlier in his career when he courageously prosecuted members of the military junta in his native Argentina. Yet, in the Darfur case, critics challenged Moreno-Ocampo's decisions to specifically charge President al-Bashir and to include the crime of genocide in the indictment. One respondent referred to the prosecutor's "bulldog style" as possibly helpful in the Argentinean cases, but detrimental in the complicated international world in which the new and fragile institution of the ICC is embedded. For this world, and also in the prosecutor's office, he and other diplomats argued, a more diplomatic approach was warranted.

Perceptions of conflict between peace and justice were most pronounced in political divisions and among diplomats with substantial experience in foreign missions. Indeed, those at the core of the diplomatic field are most dedicated to the goal of peace and most skeptical toward the pursuit of justice. Skepticism is further intensified among diplomats who had intense exposure to that part of the diplomatic field in which the government of Sudan was a key participant; for example, through work in their respective country's embassy in Khartoum.

The primacy of the peace mission, however, is not uniform in the world of diplomacy. Chapter 5 discusses Irish diplomats who-in line with their country's foreign policy emphasis on development and humanitarian aid-declared the survival of the affected population to be their first priority, placing peace second and expressing considerable skepticism for the justice mission. Such prioritizing was not surprising in Dublin's aid division, but it was at least echoed in the Political Division as well. The Irish case thus illustrates how both national context and the humanitarianism field affect priorities and strategies in the diplomatic field. Those who emphasize aid share with those who prioritize peace skepticism concerning the goal of justice-or at least concerning the primacy of justice and its pursuit by the ICC in a conflict's early stages.

Another branch in the foreign policy field, however, decisively supports the goal of justice and the ICC. Even Irish diplomats alerted me to the strong emphasis on the justice mission in their ministry's human rights division. Interviewees in political divisions elsewhere also stressed that their own focus on the peace mission was not necessarily shared 
by their colleagues in law divisions. One of them expected his human rights colleagues, as well as his minister, to take an approach more "legalistic" than his own.

Such expectations are confirmed in my interviews with two foreign ministry employees, both lawyers by training, who served in law divisions. Both insisted that the path to peace presupposes the realization of justice. One foreign ministry employee in a small country was placed in a unit on international criminal law where issues relating to Nazi-era compensation claims also fell under his jurisdiction. The other interviewee had served, until shortly before the interview, as head of an office that handled ICC issues within a division of international law. In that role he also represented his ministry on the ICC's Assembly of States. He is from the same country as the coordinator of a Sudan task force and long-term employee of his country's embassy in Khartoum whom we encountered near the beginning of this chapter. Recall that that interviewee focused most strongly on the goal of peace by means of diplomacy. In line with my expectations regarding the weight of organizational placement within the diplomatic field, the position taken by his colleague in the international law division differs markedly:

There is a tendency from a political perspective to say, well, in certain circumstances we should have peace prevail over justice. Which means, we should ... postpone a judicial prosecution or any legal proceeding against somebody, because we need that guy to have peace. And my lesson is: that is not true. Because what you consider as peace ... would not be a sustainable peace, because when I look at hundreds of thousands of victims and I accept that the injustice done against them is not taken into account, that their stories remain untold, then I cannot see how a traumatized postconflict society like this can really make sustainable peace. It is simply not possible. You need to go through that process. You need to give them justice. And once they have the feel that justice, more or less, is done or taken care of, then I think you can create within such a society a willingness to overcome postconflict and enter a new phase of peace building. ... And the political point I am making is: you don't have to do all the political work yourself, you politicians. Rely on certain aspects that can be dealt with through justice. And simply take the fruits of it. And they can be helpful for the course of your political endeavors and efforts. And that can move things forward. And you can really make a difference.

This interviewee strongly supports prosecution in the ICC, "at least for those who bear the greatest responsibility." But he also speaks about the International Center for Transitional Justice in New York and about alternative transitional justice mechanisms such as truth 
commissions and "local law" for actors such as those in low levels of the military hierarchy or "a child soldier" who "may be considered a victim himself." He cites "civil society people" who "really work at the grassroots level in Africa" and who "are reporting that things start to change ... that people at this [high] level start to realize, look, I mean, there is somebody out there who ultimately could go after me. ... We cannot accept impunity because we need something to prevent future atrocities."

I also inquired about the goals of ensuring survival and preserving the integrity of the state of Sudan. Responses show that these goals appeared much less prominently in the diplomatic field. The intensity of the goal of ensuring survival of the affected exhibited in the Irish Department of Foreign Affairs remains unique. One interviewee explicitly stated that "survival is not enough." Finally, most respondents supported division of Sudan and had given up on the notion of national integrity.

In short, the tension between the goals of peace and justice dominated responses from interviewees in foreign ministries. These goals were not necessarily seen as mutually exclusive, but the diplomatic field produces a set of clear priorities that strongly challenges the logic of the justice cascade. An unambiguous preference for peace over justice applies at least to those actors in the field who are associated with political divisions and engaged in day-to-day diplomatic work.

\section{Sources of Information}

In addition to the Sudan government's weight in the diplomatic field and the goals of its practitioners, sources of information should also influence how diplomats perceive the Darfur conflict. I thus asked interviewees what sources they consult to gain an appropriate understanding of the situation in Darfur. I did not ask them to rank their responses, but those mentioned first and spontaneously appeared especially important. All but one respondent mentioned between four and nine sources.

Several diplomats referred to their country's embassies $(n=6)$-and those who did, did so spontaneously-as one of their first three options. In the words of one interviewee: "The first source is the embassy report, which is steered by our interests [dann also entsprechend sogar gesteuert wird]. So they receive concrete questions and are asked to answer them" (author's translation). Many diplomats pointed to international organizations, specifically the UN ( $n=9$; plus UNAMID [3]), the EU (5), and 
the AU (2). While formal reports of IOs are often considered too neutral to be valuable, personal and professional contacts within these organizations are highly valued.

Note that one-third of the sources (25 out of 70-80) cited were diplomatic. And they were among the first that interviewees mentioned spontaneously when asked. The diplomatic world is thus in part a selfreferential system that produces the information it consumes. Yet this judgment would oversimplify reality if taken too far. The other twothirds of sources include NGOs (9), especially humanitarian NGOs on the ground in Sudan; think tanks and academics (7), even though follow-ups yielded few book titles or names of academics, with the exception of Alex de Waal (see the introduction); media, including Sudanese opposition media such as the Sudan Tribune and Radio Dabanga (6); and communication with Sudanese people, locally on the occasion of visits to Sudan, in the diaspora, or virtually over the Internet (5). Finally, and importantly here, only one respondent referred to court evidence. This is the same lawyer-interviewee who had served as a member of the ICC's Assembly of States and whom I cited as making a strong plea for justice.

In short, the world of diplomacy draws much of its information from national and international organizations, primarily diplomatic ones, but from other sources as well, including NGOs, media, think tanks, and Sudanese informants.

\section{REPRESENTATIONS OF DARFUR IN THE \\ DIPLOMATIC FIELD}

What representation of Darfur is then generated in a field where the government of Sudan has substantial weight, where peacemaking trumps other goals, and where information from governments and international organizations is dominant? How do diplomats interpret the causes of the conflict? Whom do they identify as responsible actors? What kinds of suffering do they acknowledge? And what do diplomats perceive to be the appropriate frame through which to interpret the violence in Sudan?

\section{Causes of Conflict}

Ten interviewees from foreign ministries spoke explicitly about the causes of the mass violence in Darfur. Two referred me to writings, 
specifically texts by Alex de Waal and by a mediator from the respondent's own ministry. Out of more than thirty arguments articulated in the relevant interview segments, those dominate that deflected responsibility from actors who were charged by the ICC. Instead, diplomats mentioned most frequently factors associated with natural or structural-political conditions. First is the process of desertification, the drought that is moving the Sahara ever further into the Sahel, and the resulting resource scarcity-an argument also common among environmentalism branches of the UN (see Smith and Howe 201 5: ch. 8). Diplomats often combine this argument with references to intergroup conflicts caused by these natural conditions, specifically conflicts between "tribes," "ethnic groups," or "nomads" and "pastoralists." Also the center-periphery conflict shows prominently as a long-term feature of the Sudanese state that eventually provoked rebellion. This argument dominates, not surprisingly, among actors with a political science education. As discussed above regarding the human rights and humanitarian fields, educational socialization colors representations in the diplomacy field. It affects habitus and doxa, taken-for-granted assumptions about reality. Diplomats further point at neighboring countries or at rebels from southern Sudan who supplied Darfur rebels with weapons to destabilize Sudan and its government.

Rarely did the aforementioned causes appear in isolation, of course. Interviewees linked them together, and their cognitive maps entail intricate causal relationships between diverse factors. Statements by the Sudan expert in the foreign ministry of a large European country illustrate such a map:

There are three main reasons why I think the crisis started. The first one is ... that the Sahara Desert was going south, so all the nomadic tribes had to go further south. There was a bigger competition for water and for wells.... So the old system of interaction between agriculture and nomads ... was challenged by that. You started to have local fighting between the different tribes. But that's what started in the mid-eighties and went on for quite a long time without becoming the big Darfur crisis we have seen. What triggered the conflict really were the two other main reasons. The first one, being a political reason, is not really specific for Darfur. It is the marginalization of all the peripheries in Sudan, compared to the center in Khartoum. Darfur used to be a kingdom before being integrated into Sudan. There is a strong memory of that in the mind of the Darfuri people. And after independence they were quite marginalized. They were completely marginalized if you look at the universities, hospitals, schools. ... And they were voicing their concerns and what they wanted, but purely politically. And that is where the third part comes in. When the Darfur crisis started, North and South were 
discussing, were starting negotiations, and at that time the mediator said: Well, if you want to negotiate, we will take only the people who have guns around the table. ... So, these Darfuri people who had more or less the same concerns as the southerners realized that ... the only solution they had to show that they existed was to take up arms and to start a rebellion.

Through such cognitive maps, the central causal factors mentioned by diplomat interviewees-namely, desertification, intergroup and centerperiphery conflict, and (as some diplomats argue elsewhere in the interviews) conflicts with southern Sudan, Libya, and Chad-interacted in the minds of diplomats. In at least three interviews the basic logic of the narrative, the stringing together of causal factors, was almost identical with that quoted above.

Implied in many arguments, and at times stated explicitly, is the long-term nature of the violence in Darfur. One respondent actually saw this violence as an element of the natural history of state formation: "The wars that Sudan now conducts, for example, Europeans conducted in the sixteenth and seventeenth centuries: wars of nation building [der nationalen Identitätsfindung], wars to settle or eliminate religious differences, ethnic wars" (author's translation). Diplomatic positions thus starkly contrast with Hagan and Rymond-Richmond's criminological "endogenous conflict theory" (2008), which explains the violence as the product of shorter-term dynamics initiated by concrete state actors to whom societal groups responded. The diplomatic explanations are congenial instead with positions taken by Alex de Waal. This homology may help explain why de Waal is the main academic reference point when diplomats refer to scholarship as a source of information.

But the focus on long-term causes does not mean that diplomat interviewees fully neglect the agency of the Sudanese state. One respondent told how the government of Sudan "armed the one side, the nomadic tribes in Darfur, to put down the rebellion." Another insisted that the violence "certainly emanated initially from the rebel side," but, he continued, "it was the scale of the reaction by Khartoum that exacerbated the entire situation." Yet another interviewee reported that the patterns in Darfur were typical strategies of the Sudanese government: "It happened in the South before; it happened in Blue Nile and Southern Kordofan as well. They consider their army isn't strong enough to fight against the rebellion, so they use proxies to support the army, and what they did learn was to use Arab tribes, tribes that consider themselves as Arab, which is mainly nomadic tribes, telling them: 'Well, we'll give you 
weapons. You fight against those other tribes ... and you take whatever you want."'

While references to the Sudanese state are thus not absent when diplomats discuss causes of the violence, they appear less prominently than do ecological and structural forces. In addition, diplomats tend to avoid naming specific actors. They certainly remain more general than position holders in the criminal justice system or in human rights-based NGOs. But would they maintain their reluctance if asked not generally about causes, but specifically about responsible actors?

\section{Asking about Actors}

Ten interviewees from the world of diplomacy commented on actors with potential responsibility for the mass violence in Darfur. While they mostly spoke about the government of Sudan, the Janjawiid, and rebel organizations as collective actors, some referred occasionally to President al-Bashir and Ahmed Harun as individuals. Respondents certainly never expressed doubt that the government of Sudan bore responsibility. But, not accidentally, a respondent, educated as a lawyer and from the law division of a large European country's foreign ministry, argued most clearly:

It is obvious to me that the most serious crimes have been committed. It is obvious to me that government institutions, in one way or the other, have to be held responsible. They share certainly some responsibility with regard to those crimes. And I will also say that if things like that remain without a judicial response, then ... [perpetrators] get the message you can do all those things and . . . nothing happens. This is impunity. Impunity prevails. And I think the ICC is about the message to say impunity is over.

Yet even this interviewee also adds, somewhat diluting the previous point:

There is too much focus on the perpetrators. We should much more focus on the victims, and in doing so, I think we get much closer to what actually needs to be done to remedy the situation. But, apparently when you operate in a media-dominated environment, it is of course sexier to have some kind of rogue guy sitting on the bench before the court than possibly having embarrassing interviews with faceless victims.

Other diplomats also spoke to the responsibility of the government of Sudan. "It was a series of the gravest offenses against human rights," one said, "for which—as we know today—-the government was responsible" (author's translation). Focusing on the violence committed by 
the Janjawiid, another respondent added: “Obviously, in terms of responsibility, you also do have to look at the government." A colleague confirmed: "I am convinced that the northern government was involved in the violence perpetrated by those groups who initiated it" (author's translation). Yet another diplomat insisted: "The government in Khartoum has a lot of experience in using proxies, in the South as well, ... in using tribes or groups of people." While the responsibility of the government of Sudan was thus highlighted, most respondents avoided casting it explicitly in terms of criminal liability. Some interpreted the government's responsibility explicitly as political responsibility: "I think it remains not an ICC matter, but it remains an issue to be brought to the account of the Khartoum government, for having arrived at a point where it has effectively either ungoverned or misgoverned spaces in its own country. . . It is a political charge against the Khartoum government as much as a charge in relation to direct accountability.”

In short, respondents almost unanimously held the government of Sudan accountable for the violence. Some specified organizational units such as the military and the Popular Defense Forces. But diplomats simultaneously urged against focusing on the perpetrators and on criminal responsibility alone, but attending instead to the victims and broadly conceived political responsibility. They rarely named specific government actors. When mentioning al-Bashir directly, interviewees combined such mention with partly exculpating statements. One interviewee reported on conversations he had had with President al-Bashir, describing him as a man "who realizes today that he was fooled in many things . . . by his own people" (author's translation). Another respondent supported this sentiment: "In how far Bashir was informed about everything, I cannot really tell you." The interviewee then drew parallels with North Korea's Kim Il Sung: "He [Kim] was so cut off from the world that he just did not have any direct experience any more. . . I I think in the case of Bashir that he must have understood what kinds of decisions he supported and consented to. But I do not dare to say if he really knew about the real scale, but I personally have to say truthfully: I doubt it. I have met him three times thus far; I cannot easily be misled in these things" (author's translation).

Diplomats also occasionally named Ahmed Harun, until 2009 the Sudanese minister for humanitarian affairs, as a responsible, albeit instrumentalized, actor. One respondent considered Harun "one of the main tools used by the government to put in place these policies of proxy militias, recruiting the militias and using the local population, 
fueling the conflict, to make sure the army was not too much involved. [JJS: And used by whom?] Well, that is the big question as well"-a question, though, for which the respondent did not provide an answer.

In addition to the government, broadly conceived, and two specific government actors, the Janjawiid appear prominently in the interviews as responsible actors. But this attribution too was relativized in numerous ways. One respondent referred to Janjawiid militias as accomplices ("Erfüllungsgehilfen"). In the eyes of another diplomat they were "being armed by the government, paid for by the government." A third interviewee went into greater detail, deciphering the conditions of the nomadic groups from which the militias were recruited. His narrative challenges notions of the Janjawiid common in the criminal justice field:

I don't like the term Janjawiid very much, because it suggests a sort of ultimate evil, and it's not very helpful in terms of gaining a differentiated understanding of the conflict.... So, on the surface of things—and this is very much how the conflict has been portrayed-you have Arabs, so the Arabbased Sudanese government and Arab tribes forming these militias, being the perpetrators. And you have non-Arabs being the victims. . . . Now, if you take a step back, ... you can reverse the image because, as it stands, the Arabs, the nomad Arabs in Darfur, are in many ways the most marginalized group in Darfur. Because they are nomads, they don't have any homeland, and as the desert is advancing, they lose their livelihoods. They are camel breeders, and you can't have camels in the desert. Right. So they lost their livelihoods. They have no lands to go to.... They lost their identity as well, which was very much tied to camels, camel trade, and took [up] arms very much in an attempt to defend themselves. Right. So you could look at them as victims as well.

Simultaneously, the same respondent attributed greater responsibility to rebels than we typically encounter in social movements such as Save Darfur or in the criminal justice or human rights NGO narrative, even with some charges having been filed against lower-ranking rebels:

If you look at the history of the conflict, the rebellion comes from non-Arab tribes. They started this whole thing. And rebels are called rebels because they hold guns and they kill people. Right. So they are perpetrators as well. And so, while the distinction between victims and perpetrators appears obvious in Darfur, I would suggest that it actually isn't, and it is much more complicated. And by even using the labels victims and perpetrators, we conflate things, and we contribute to an understanding of this conflict which really isn't very helpful if you want to resolve it.

Another interviewee also cast the rebels in a highly problematic light: "That the JEM is primarily interested in justice and equality, that I do 
not quite believe. No, those are criminals [Verbrecher]. . . . One of them plays a central role. He sits in Paris and always says 'no.' So he does not really want a solution and impedes the Doha talks" (author's translation).

In short, when explicitly asked about actors with responsibility for the mass violence in Darfur, diplomats do not shy away from attributing responsibility to the government of Sudan. Yet they tend to frame it as broad political responsibility. They name individuals only rarely and-when they do-tend to cast doubt on their criminal liability. Several interviewees attribute responsibility to the Janjawiid, but they too relativize. Some respondents divert responsibility away from the militias and toward rebel groups, thus countering the dominant narrative of pro-criminal justice actors such as the Save Darfur movement and the ICC itself. Clearly, the responsibility narratives of diplomats reflect the strong role of the Sudanese state in the field in which diplomats act and the substantive, outcome-oriented goals of diplomatic work.

\section{Suffering}

Nine diplomats responded to my inquiry about the Darfuri population's victimization and suffering, but only four specified forms of suffering. One respondent from a small European country spoke about people "forced to leave their homes and villages, and their villages have been burned down; their number is estimated at two million." An interviewee from another small country referred to "all these displacements, ... in many different directions; there have been refugee camps" (author's translation). A diplomat from a large European country addressed suffering in the context of the relative success of international interventions: "I think [UNAMID] has had an effect; the fighting and the displacement is less than it was at the height of it in 2005 , but it is still ongoing. And the government is still bombing civilians. The rebels are still fighting." Only two diplomats elaborated on the suffering in greater detail. One, the interviewee from Irish Aid within Ireland's Department of Foreign Affairs, described compassionately the displacement of (her numbers) I.5 million people; lack of shelter, water, food, and protection; the deaths of 200,000; and systematic rape campaigns. At the same time, however, she cautioned that "if you look at the media coverage of those years, it was quite sensationalized." The other respondent who detailed the suffering and victimization in Darfur was 
a diplomat from a large European nation's foreign ministry, a specialist with responsibility for Sudan:

The interesting thing in Darfur is that most of the people who died didn't die from bullet wounds... . They lead them to camps so that they could control them easily. And whenever people were getting outside, you could see the women getting raped and all of that. ... They were fighting a psychological war against the local population, using terror against this population. So I think that is . . . one of the things people suffer the most from. After the very first ... period of military operations, that didn't last very long-it lasted one year, a bit more than a year-but once everyone was in camps or refugees outside in Chad, the way that the army and these Popular Defense Forces, the Janjawiid who were fighting against the rebels, was to try to use terror against the population, so that they would denounce and try to build a gap between the population and the rebels. Death was another form of suffering, what happened inside the camps because of unsanitary conditions and so on, and rape as a systematic strategy of spreading terror.

While diplomats spoke sparingly about suffering, several interviewees explicitly challenged the victimization numbers that appear often in human rights discourses. One interviewee from the legal division of his foreign ministry deferred to the Africa Department because, from a legal perspective, the precise number of victims was irrelevant. $\mathrm{He}$ elaborated that a trial always focuses on just the few cases for which evidence is strong. Another respondent found it "very hard to have access to objective information, very hard to say something about those figures." A diplomat from a large European country explicitly critiqued numerical estimates. This interviewee attributed the prominence of certain numbers in public discourses to media reports, but their origins to NGOs: "[Mass media] publish the first numbers. ... The high commissioner for refugees or such, he does not count himself; he lets others count and says: 'Care, Oxfam, Deutsche Welthungerhilfe, Red Cross, how many do you have, roughly?' And those, in the middle of a crisis, completely overworked, their hands full, look around; 'well this must be I 50,000 now, plus-minus.' And that is how these numbers are constructed. And that then solidifies" (author's translation). ${ }^{5}$

Another senior diplomat from a small European country-a longterm advisor on international affairs to a leading head of state who, during his lifetime, had enjoyed extraordinary respect in much of the Global South-expressed the same skepticism. Indeed he developed the critique further, claiming that NGOs have a vested interest in exaggerating numbers: "The NGOs have a completely understandable interest 
rather to dramatize because that also improves their financial basis, so to speak. They can secure financial donations much more easily with a dramatizing report than without it" (author's translation). The same interviewee was highly critical of some countries—especially the United States-that, in his perception, advanced dramatizing accounts. "The former foreign minister of Congo," he said, "who then became special envoy for Darfur to the AU and the UN, who one day declared, 'Well, really, the issue of Darfur is now taken care of, things have largely settled down,' he subsequently lost his job. The UN then said: 'Who do you think was behind that?' Well, the Americans who said: 'We do not have use for someone like that at the current moment'" (author's translation).

This interviewee attributed "exaggerations" to national conditions and political interests, somewhat in line with social scientific arguments. Specifically for the US government, he referred to the activation of civil society and the government's responsiveness. He highlighted Christian fundamentalist groups with a strong presence in South Sudan and oil interests: "For the Americans . . . such things then become issues of domestic politics. When you have a Brad Pitt and a George Clooney appear before a large audience, . . . then people look on and they ask: 'Why does our government not do anything?' . . . That all matters in the question of opinion formation. Truth, published opinion, perceived opinion in the public-these are all different things" (author's translation).

The same diplomat attributed similar tendencies to exaggerate victimization in Darfur to the French government. But there, he believed, the motivation differs:

In France, I know, for example, that the francophone African countries all have an enormous influence on domestic politics. They are all present in Paris. They have their French representative [in the National Assembly] with whom they are friends. An African president picks up the phone and calls the French president, and if he does not reach him right away, then he gets at least to talk to the general secretary, and that is all taken very seriously. ... In the case of Sudan, France also supported a dramatization, exactly because they perceived Sudan as a potential aggressor against [francophone] Chad. They portrayed Sudan in a completely negative light, and in that question they did not differ that much from the Americans. (author's translation)

In short, actors in the diplomatic field who interact with representatives of the Sudanese state, whose primary aim it is to achieve peace by means of negotiation, and whose explanations of the conditions of the 
conflict tend to deflect responsibility away from specific individuals, including those indicted by the ICC, simultaneously shy away from questions that probe the suffering and victimization of the population. They instead tend to challenge and cast doubt on narratives generated and diffused by human rights NGOs and criminal justice institutions. Given the intensity of diplomatic concerns about replacing mass violence with peace, it is hard to attribute such patterns to a lack of empathy with those who are suffering. But it appears as though the regular and intense articulation of victimization narratives comes more easily to those who work in the human rights and criminal justice fields, areas in which the Sudanese state and its representatives are not critical actors.

\section{Framing Mass Violence}

What frames do actors in the diplomatic field consider appropriate for the interpretation of the mass violence in Darfur? Here too I asked interviewees to comment on the applicability of four frames: humanitarian emergency, civil war, insurgency and counterinsurgency, and state crime. Almost all respondents found the humanitarian emergency frame appropriate. The Irish Aid respondent in fact identified this frame as "particularly relevant." Other responses to my inquiry about the term included "Exactly, yeah"; and "That it is for certain." One interviewee saw a humanitarian emergency as having occurred in the past, but no longer existing in the present: "2004-2005, possibly into the second half of $2006 ; \ldots$ and then this turned into a case of reconstruction and return" (author's translation). Only one respondent from the diplomatic field expressed doubts, arguing that the humanitarian emergency frame "doesn't really tell you anything about the nature of a crisis. Crises, and especially when they result in armed conflict, are always political."

Most respondents also agreed that a rebellion or insurrection frame is appropriate for an interpretation of the violence, though some limited such framing to the early phases of the conflict. "That fits somehow," one interviewee said. "I mean, in the end it is a lot about marginalized people who stand up for their rights." Four respondents disagreed with the insurrection frame. One argued that the term protest is more appropriate, as rebellion implied separatist intent, which, he argued, did not apply to Darfur. Diplomats almost unanimously rejected the civil war frame, even though one interviewee referred to the violence as similar to civil war ("bürgerkriegsähnlich"). More typical was a statement that 
rejected the notion of civil war: "It is not a civil war, because Darfur never explained that it sought independence."

Finally, and astonishingly in light of their causal analysis and assessment of victimization, most diplomats considered the state crime frame appropriate, but they expressed some kind of reservation. "The state has a clear responsibility," one respondent told me. "They didn't act upon the crimes that have been committed. ... There is no justice being done. I think it is obvious that the state is involved in these crimes or at least has responsibility." This and another respondent considered the (in)actions of the Sudanese state as crimes more of negligence than of its own aggression. Others pointed out that crimes were committed on both sides of the conflict. An interviewee from a small European country deemed the term state crime appropriate, but insisted that such understanding was not shared by African actors: "State crime? Yes, for us unambiguously, but for the Africans not quite so clearly." Earlier in the interview he argued: "One regards this in Sudan as normal intervention" (author's translation), and he referred to growing African skepticism about the ICC. At least one respondent appeared to have developed sympathies with the AU position. He expressed a clear preference for a "traditional" justice response as opposed to international criminal justice intervention.

In addition to such cautious applications of the state crime frame, I also encountered staunch opposition. One actor from the diplomatic field, trained as a political scientist with a focus on international relations, explicitly challenged the state crime frame, pleading instead for a political-structural mode of understanding the conflict:

I don't find it [the state crime label] a helpful lens, because if you look at the history of Sudan, since independence in ' 56 , you have different regimes, right? You have democratically elected regimes, you have military regimes, and in the last twenty-two years an Islamist regime, right? They function very differently, have different constituencies that they draw on, different political strategies to secure their rule. Yet mass atrocities happened in all of these regimes. So there is something, I think, systemic that the way in which the Sudanese state functions produces mass violence in certain ways. And by focusing on a few individuals-and since the ICC indictment, a lot of people in the West have focused on the role of President Bashir-and to see the conflict in Darfur in a way as an outcome of the criminal energy of Omar al-Bashir and his acolytes is not actually accurate in terms of understanding why the conflict emerged in the first place, and why the Sudanese government has been engaging in these kinds of atrocities.

Quantitative patterns from an analysis of 2 Io foreign ministry press releases, by definition written to reach a broad public, show a somewhat 
greater balance (see note 2). Yet, while references to the frames of conflict and war $(25.7 \%)$ and humanitarian emergency $(28.6 \%)$ are privileged only somewhat over the crime frame $(20.5 \%)$, the patterns for preferred solutions fall in line with responses cited throughout this chapter. Fifty-one percent of press releases suggest diplomatic solutions. Humanitarian aid $(35 \%)$ and peacekeeping operations $(39 \%)$ also appear prominently, while legal solutions (I०\%) and especially military intervention ( $\mathrm{I} .4 \%$ ) lag far behind. ${ }^{6}$

In short, interviewees from the world of diplomacy display patterns of thought, partly consistent with quantitative findings emerging from an analysis of foreign ministry press releases that cautiously embrace the frame of humanitarian emergency to cast light on the situation in Darfur. They apply the insurgency and counterinsurgency frame at least to the early stages of the conflict. They are skeptical about the civil war frame, and they cast substantial doubt on the applicability of the state crime frame. This is consistent with the tendency of the diplomatic field to attribute the violence to ecological catastrophe, resulting intergroup conflicts, or to structural features of the Sudanese state. It is similarly in synch with reluctance to point at specific responsible actors, especially individuals.

\section{CONCLUSIONS: THE DIPLOMATIC FIELD AND HABITUS-AND WORDS OF CAUTION}

The diplomatic field displays specific features that differ from those of the judicial and humanitarian fields. The diplomatic field prominently includes Sudanese state actors. While this field shares this factor with the humanitarian field, diplomacy depends on the active participation of-often high-ranking-Sudanese government actors, whereas humanitarian aid more often relies on mere toleration on the part of lower-level and specialized government administrations. Despite this distinction, the humanitarian and diplomatic fields differ from the judicial field not just in their engagement with actors from the offending government but also in that they are less oriented toward procedure than toward substantive outcomes, with a focus on survival in the former and peace in the latter. Actors in the diplomatic field, just like those in the justice and humanitarian fields, strongly identify with their mission. They have internalized their field's institutional logic and its doxa. All of this is in line with field theory, as are the respective representations of the Darfur conflict in these fields. 
Indeed, diplomats used cautious language in interviews when describing the conflict. Causes of conflict that diplomats highlighted privileged ecological conditions; structural features of the Sudanese state, often historically rooted; and neighboring African interests and conflicts. While they did mention the Sudanese state as a responsible actor, they mostly avoided pointing at specific individuals as responsible for the violence. When they named individuals, especially President al-Bashir, they tended to provide exculpating considerations. Most were more sparing in their accounts of victimization and suffering than their counterparts in the justice and humanitarian fields. Finally, diplomats used substantial caution regarding the applicability of the state crime frame. They were especially reluctant to using the term genocide.

The latter finding is consistent with Samantha Power's (2002) assessment of US foreign policy and with Karen Smith's (20I0) analysis of three European countries. Yet, while Power and Smith explain such caution by pointing to the reluctance of rational actors to incur obligations associated with the use of the term genocide, I argue that features of the diplomatic field and the notion of habitus must be built into an effective explanation. Achieving the substantive goals of diplomacy warrants an inclusionary strategy toward actors of the regime that the justice system seeks to exclude by way of prosecution. It urges distance from dramatizing discourses and from narratives that depict social reality through the lens of the justice system.

In short, a diplomatic master narrative, or in other words, an ideal type of diplomatic representation, focuses on long-term and structural causes of conflicts. It avoids naming responsible actors. It shies away from dramatic depictions of victimization. And it rejects the state crime frame, especially the notion of genocide. It is diametrically opposed to Hagan and Rymond-Richmond's (2008) criminological "endogenous conflict theory," which explains the violence as the product of shortterm dynamics in which concrete state actors play a central role.

Real types, of course, differ from ideal types. This applies to representations of the Darfur conflict. Even the variation within my relatively small sample of interviews, supported by statistical patterns from foreign ministry press releases, suggests differentiation along lines of organization and educational background. Diplomatic actors with legal training are somewhat more inclined to deviate from the diplomatic master narrative than those with a political science background, which is consistent with my findings for lawyers in human rights organization and the humanitarian field. This tendency is amplified for 


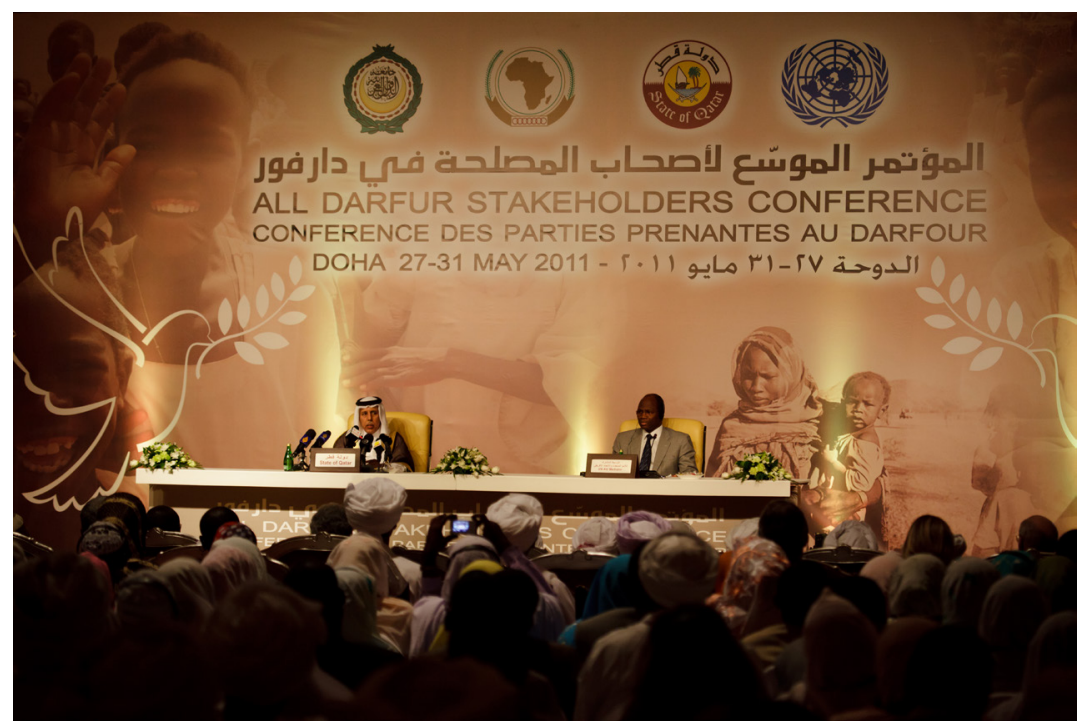

FIGURE I 7. Signing of the treaty that emerged from the Doha peace negotiations, July I4, 20I I.

lawyer-diplomats who work in legal divisions and, even more so, in human rights units within their foreign ministries. The latter diplomats' representation of Darfur actually approximates the justice narrative. Fields, like systems, are thus scholarly constructions. In reality they overlap with other fields, diachronically (through educational socialization) and synchronically (through organizational differentiation)-here within the diplomatic field.

But one more factor needs to be accounted for. The diplomatic field is affected by national contexts. Each nation provides for particular forces that shape its diplomats' habitus and strategic actions. It is such crossnational differences and the social forces that shape them to which I now turn. 